\title{
A medical device forming a protective barrier that deactivates four major common cold viruses
}

\author{
Bjarki Stefansson ${ }^{1 *}$, Ágústa Gudmundsdottir ${ }^{1,2}$ and Mats Clarsund ${ }^{3}$ \\ ${ }^{1}$ Zymetech, Reykjavik, Iceland \\ ${ }^{2}$ Faculty of Food Science and Nutrition, Health Sciences Division, University of Iceland, Reykjavik, Iceland \\ ${ }^{3}$ Enzymatica AB, Lund, Sweden
}

\begin{abstract}
The medical device ColdZyme is a mouth spray that forms a barrier in the throat against common cold viruses. The barrier solution of the device is composed of glycerol and Atlantic cod trypsin. The aim of this study was to evaluate the virus deactivating ability of ColdZyme against four major common cold viruses. A virucidal efficacy suspension test was conducted using ColdZyme against each of the challenge viruses in suspension. ColdZyme deactivated rhinovirus type $1 \mathrm{~A}$ by $91.7 \%$ (1.08 $\left.\log _{10}\right)$, rhinovirus type 42 by $92.8 \%\left(1.14 \log _{10}\right)$, human influenza A virus $\mathrm{H} 3 \mathrm{~N} 2$ by $96.9 \%\left(1.51 \log _{10}\right)$, respiratory syncytial virus $(\mathrm{RSV})$ by $99.9 \%\left(2.94 \log _{10}\right)$ and adenovirus type 2 by $64.5 \%\left(0.45 \log _{10}\right)$. Based on the results, ColdZyme showed an effective broad-spectrum impact against common cold viruses. Thus, ColdZyme might represent a device with clinical benefits in prevention and treatment of respiratory viral infections by deactivating viruses within the respiratory tract.
\end{abstract}

\section{Introduction}

Common cold is known to be a heterogeneous group of diseases caused by numerous viruses $[1,2]$. It has been estimated that rhinovirus accounts for most clinical cases followed by influenza viruses, human coronaviruses, RSV, parainfluenza and adenoviruses [2-5].

In designing an effective treatment against the common cold the variability of respiratory viruses involved must be considered. These include the complex structures of respiratory viruses, the variety of viral surface proteins essential for infection, the different pathways important for infection and the fact that viruses mutate frequently that may result in treatment difficulty [6]. It could be beneficial to design treatments to act topically on the surface of the oropharynx as most cold viruses are present on the throat's outer lining during infection [7]. Therefore, it would be beneficial for an effective treatment against the common cold to involve a protective barrier that deactivates common cold viruses as well as other viruses. Furthermore, it would be important to specifically target locations where viruses infect and spread (i.e. nose and throat) with a treatment that at the same time has a high safety profile to match a mild disease such as the common cold. ColdZyme ${ }^{\infty}$ Mouth Spray (ColdZyme) [8] is a medical device designed to possess these traits. The device is a viscous solution containing primarily glycerol and cod trypsin that is deposited on the mucous membrane of oropharynx. ColdZyme is intended to directly inhibit infection by blocking viruses at their point of entry, reduce the probability of catching a cold and help shorten the duration of a cold. Cod trypsin is an enzyme that can degrade proteins and degradation of protein structures presented on the viral surface is considered to contribute to the virus deactivating impact of ColdZyme.

In this study, the virus deactivating impact of ColdZyme was measured by assaying its potential to deactivate four major common cold viruses in suspension.

\section{Materials and methods}

\section{ColdZyme mouth spray}

The ColdZyme solution contained glycerol, water, cod trypsin, ethanol $(<1 \%)$, calcium chloride, tris and menthol. Two lots were evaluated; Lot 13442 (production date 2017-04-17) and Lot 13028 (production date 2017-01-02).

\section{Laboratory}

Testing according to ASTM International E1052-11 method, "Standard Test Method to Assess the Activity of Microbicides against Viruses in Suspension' was carried out by an independent testing laboratory under GLP conditions; Microbac Laboratories, Inc., 105 Carpenter Drive, Sterling, VA 20164, USA.

\section{Cells and virus strains}

Challenge viruses: Rhinovirus Type 1A (RV1A) (HRV-A), strain: 2060, ATCC VR-1559, Rhinovirus Type 42 (RV42) (HRV-B), strain: 56822, ATCC VR-338, Influenza A Virus (H3N2), A/Hong Kong/8/68, Charles River Laboratories, Respiratory Syncytial Virus (RSV), strain: Long, ATCC VR-26 and Adenovirus Type 2 (AD2), strain: Adenoid 6, ATCC VR-846. Host cells and culture media used: H1-HeLa cells ATCC CRL-1958 (for RV1A and RV42) in Roswell Park Memorial Institute (RPMI) $1640+10 \%$ Fetal Bovine Serum (FBS), MDCK cells ATCC CCL-34 (for Influenza H3N2) in Eagle's Minimum Essential Medium (1X MEM) + 10\% FBS, HeLa cells ATCC CCL-2 (for RSV) in

Correspondence to: Bjarki Stefansson, Zymetech, Fiskislod 39, 101 Reykjavik, Iceland, Tel. +354-551-5400; E-mail: bjarkis@zymetech.com

Key words: medical device, common cold, virus, trypsin, ColdZyme ${ }^{\circledast}$ Mouth Spray

Received: October 27, 2017; Accepted: November 08, 2017; Published: November 14, 2017 
Dulbecco's Modified Eagle Medium (1X DMEM) + 10\% FBS and A549 cells ATCC CCL-185 (for AD2) in DMEM + 10\% FBS.

\section{Viral deactivation test}

Two lots of ColdZyme were evaluated against a challenge virus in suspension. For each run, a $1.2 \mathrm{~mL}$ aliquot of each lot of ColdZyme was mixed with $1.5 \mathrm{~mL}$ of phosphate buffer $(1 \mathrm{xPB})$ without sodium chloride, pH 7.5 and $0.3 \mathrm{~mL}$ of the challenge virus suspension (each virus was tested independently) and mixed thoroughly by vortexing. The reaction mixtures were incubated at $35-37^{\circ} \mathrm{C}$ for 20 minutes (contact time). After incubation, an aliquot or the entirety of the reaction mixture was immediately mixed with an equal volume of neutralizer. The neutralizer was $100 \%$ FBS for all viruses tested except Influenza H3N2 where it was minimum essential medium (MEM) + $10 \%$ FBS. The quenched sample was serially diluted with medium in tenfold increments and inoculated onto host cells to assay for infectious virus. After incubation for $90 \pm 10$ minutes, cells were washed with phosphate buffered saline (PBS), refed with fresh medium and returned to incubation. Inoculated plates were incubated at $33 \pm 2^{\circ} \mathrm{C}$ in $5 \pm 3 \% \mathrm{CO}_{2}$ for 6-9 days for HRV-A and HRV-B, at $36 \pm 2^{\circ} \mathrm{C}$ in $5 \pm 3 \% \mathrm{CO}_{2}$ for $4-6$ days for Influenza H3N2, 11-14 days for AD2 and 14-18 days for RSV. After incubation, the cultures were scored for viral infection by determining viral-induced cytopathic effect (CPE).

The titer of the virus $\left(\log _{10}\right.$ TCID50/ml) was calculated using the Spearman-Karber formula [9] or Poisson distribution when no virus was detected [10].

\section{Controls}

Controls included a virus recovery control, neutralizer effectiveness/viral interference control, a cytotoxicity control, a media negative control, a virus stock titer control and a reference product control. The neutralizer effectiveness/viral interference control was performed in order to determine if residual active ingredients were present after neutralization and if the neutralized test substance interfered with virus infectivity. A mixture of $1.2 \mathrm{~mL}$ of ColdZyme and $1.5 \mathrm{~mL}$ of $1 \mathrm{xPB}$ without sodium chloride, $\mathrm{pH} 7.5$ was mixed thoroughly with $0.3 \mathrm{~mL}$ of medium (in lieu of the challenge virus), held for contact time at $35-37^{\circ} \mathrm{C}$, and then neutralized. The sample was then serially diluted in tenfold increments using dilution medium. Each dilution was divided into 2 portions, one for neutralizer effectiveness/viral interference control, and the other for cytotoxicity control. For the neutralizer effectiveness/viral interference control, $0.1 \mathrm{~mL}$ of a low titered virus was added to $4.5 \mathrm{~mL}$ of each dilution and held for a period equivalent or greater than the contact time. After incubation, the virally spiked dilutions were inoculated onto host cells. For the cytotoxicity control, the sample obtained from the neutralizer effectiveness/viral interference control run was serially diluted and inoculated onto host cells. The condition of the host cells was recorded at the end of the incubation period. For the virus recovery control, a $1.2 \mathrm{~mL}$ aliquot of medium (in lieu of ColdZyme) was mixed with $1.5 \mathrm{~mL}$ of $1 \mathrm{xPB}$ without sodium chloride, $\mathrm{pH} 7.5$ and $0.3 \mathrm{~mL}$ of the challenge virus suspension. The mix was held for the contact time and then neutralized as for the test product runs. The quenched sample was serially diluted with dilution medium in tenfold increments and selected dilutions were inoculated onto host cells to assay for infectious virus. The virus recovery control results were used as the input viral load and compared with the results for ColdZyme treatment to evaluate viral reduction by ColdZyme. For the media control, at least 4 wells were inoculated with media in each assay to demonstrate that cells remained viable and media was sterile throughout the assay. For the virus stock titer control, an aliquot of the virus was serially diluted and inoculated directly onto host cells. This was to demonstrate that the titer of the stock virus was appropriate for use and that the viral infectivity assay was performed appropriately. For the reference product control, a $1.2 \mathrm{~mL}$ aliquot of a $2000 \mathrm{ppm} \mathrm{NaOCl} \mathrm{NaOCl}$ containing bleach solution was mixed with $1.5 \mathrm{~mL}$ of $1 \mathrm{xPB}$ without sodium chloride, $\mathrm{pH}$ 7.4-7.5 and $0.3 \mathrm{~mL}$ of the challenge virus suspension. The mix was held for the contact time and then neutralized. The quenched sample was serially diluted with dilution medium in tenfold increments and selected dilutions were inoculated onto host cells to assay for infectious virus.

\section{Results}

To determine the virus deactivating ability of the ColdZyme solution, each of the viruses tested was incubated with ColdZyme as described under materials and methods. Samples from each incubation were titrated with the $50 \%$ Tissue Culture Infectious Dose (TCID50) endpoint assay using the appropriate host cell system for each virus.

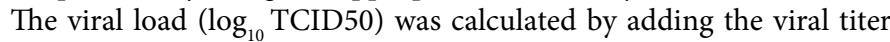
$\left(\log _{10}\right.$ TCID50/mL) to the $\log _{10}$ (the volume of reaction mixture in $\mathrm{mL}$ times the volume correction). The volume correction accounted for the neutralization of the sample post contact time. The Input Load in Table 1 represents the virus units $\left(\log _{10}\right.$ TCID50) recovered after incubating the virus in medium before inoculation (virus recovery control, see materials and methods) and the Output Load represents the virus unit $\left(\log _{10}\right.$ TCID50) recovered after mixing and incubating the virus in presence of ColdZyme.

The $\log _{10}$ reduction factor was calculated by subtracting the output

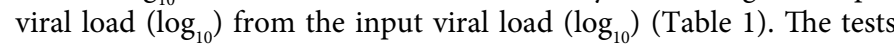
were conducted in duplicate for each ColdZyme lot and for the viral recovery control and the mean is reported (Table 1). As can be seen in Table 1, ColdZyme deactivated all the viruses tested. The viral stock titer control for each assay confirmed that the appropriate titer was used in the experiment and sufficient amount of virus was recovered for the virus recovery control (data not shown). No virus was detected in the cell viability control wells, the cells remained viable and the media was sterile. Virus was detected in all the neutralizer effectiveness/ viral interference control wells. Cytotoxicity was not detected at any dilution or cell line tested. Viral-induced CPE was distinguishable from uninfected cells. Thus, all the controls met the criteria for a valid test. The reference test substance, $2000 \mathrm{ppm} \mathrm{NaOCl}$, had a log reduction of $>3.3$ for all viruses tested.

\section{Discussion}

The goal of this study was to determine the ability of ColdZyme to deactivate several of the major viruses known to cause common cold in humans. ColdZyme deactivated all viruses tested from $64.5 \%$ to $99.9 \%$ when incubated with each virus for 20 minutes at $35-37^{\circ} \mathrm{C}$. The deactivating impact was higher for enveloped viruses such as RSV and influenza compared to nonenveloped viruses such as rhinovirus and adenovirus. The results indicate that ColdZyme can offer a protective barrier against a wide spectrum of harmful viruses.

The basis for the use of ColdZyme against the common cold is thought to partly depend on the ability of trypsin in cleaving proteins on the surface of viruses important for infection. This will inhibit viruses in binding to cellular receptors and thereby infecting host cells. Trypsin cleaves proteins on the carbonyl side of the amino acids arginine and lysine. Multiple numbers of these amino acids are frequently found within proteins that can explain the deactivation of a wide spectrum of viruses by ColdZyme. Trypsin from Atlantic cod (Gadus morhua) has been shown to have higher catalytic efficiency than comparable enzymes [11-15]. Furthermore, native proteins, such as those found on 
Table 1. Virus deactivating ability of ColdZyme. ${ }^{\dagger}$ Mean of two experimental values.

\begin{tabular}{|c|c|c|c|c|}
\hline Virus & $\begin{array}{c}\text { Input Load } \log _{10} \text { TCID50 } \\
(\text { Mean })^{\dagger}\end{array}$ & $\begin{array}{r}\text { Output Load } \\
\log _{10} \text { TCID50 } \\
(\text { Mean } \pm \text { SD) }\end{array}$ & $\begin{array}{c}\log _{10} \text { Reduction } \\
\text { (Mean) }\end{array}$ & $\begin{array}{c}\text { Percent } \\
\text { Deactivation }\end{array}$ \\
\hline $\begin{array}{l}\text { Influenza A Virus (H3N2), A/Hong Kong/8/68, Charles River } \\
\text { Laboratories }\end{array}$ & 4.87 & $3.36 \pm 0.14$ & 1.51 & 96.9 \\
\hline Respiratory Syncytial Virus (RSV), strain: Long, ATCC VR-26 & 5.23 & $2.29 \pm 0.13$ & 2.94 & 99.9 \\
\hline Rhinovirus Type 1A(RV1A) (HRV-A), strain: 2060, ATCC VR-1559 & 5.37 & $4.29 \pm 0.13$ & 1.08 & 91.7 \\
\hline Rhinovirus Type 42 (RV42) (HRV-B), strain: 56822, ATCC VR-338 & 5.62 & $4.48 \pm 0.20$ & 1.14 & 92.8 \\
\hline Adenovirus Type 2(AD2), strain: Adenoid 6, ATCC VR-846 & 4.62 & $4.17 \pm 0.13$ & 0.45 & 64.5 \\
\hline
\end{tabular}

the surface of viruses, appear to be more readily hydrolyzed by cod trypsin [15].

Cod trypsin is more sensitive to inactivation by heat and $\mathrm{pH}[12-$ 14] that thereby limits the duration of activity and ensures that the trypsin only exhibits a controlled localized impact within the barrier displaced in the throat. Also, important for the localized impact is the fact that the oral mucous membrane is known to have various ways to protect itself from proteolytic enzymes such as trypsin. This protection is provided by high amounts of trypsin inhibitors in the mucosa and the heavily glycosylated mucins, the major proteins lining the oral mucosa [16-18]. As many foods contain high amounts of proteolytic enzymes [19], protection by protease inhibitors and by other means is an essential function of the human body.

It should be noted that the ColdZyme solution was diluted 2.25-fold in phosphate buffer before adding virus and therefore the deactivating impact in vivo could be even higher than shown in Table 1. The performance of ColdZyme as a protective barrier against common cold virus has been confirmed in a clinical study on healthy volunteers inoculated with rhinovirus [8]. In the study, the total viral load in the oropharynx was significantly (by a factor of $10^{8}$ ) lower and the number of days with manifested common cold symptoms was reduced from 6.5 days to 3 days in the group using ColdZyme compared to the placebo group.

The results show that ColdZyme deactivates rhinovirus type $1 \mathrm{~A}$ and type 42 , human influenza A virus H3N2, RSV and adenovirus type 2 in a virucidal efficacy suspension test. Based on this and other studies, it is concluded that ColdZyme offers a protective barrier against the major common cold viruses. Therefore, ColdZyme might represent a device with clinical benefit in prevention and treatment of respiratory viral infections such as the common cold by deactivating viruses within the respiratory tract.

\section{Acknowledgements}

The authors thank Hulda S. Hreggvidsdottir and Reynir Scheving for their work and support.

\section{Competing interest}

Bjarki Stefansson and Ágústa Gudmundsdottir hold shares in Enzymatica $\mathrm{AB}$ and are employed at Zymetech that is fully owned by Enzymatica $A B$ in Sweden. Mats Clarsund was employed at Enzymatica $\mathrm{AB}$ during the study. Enzymatica $\mathrm{AB}$ manufactures and sells ColdZyme ${ }^{\oplus}$ Mouth Spray.

\section{References}

1. Heikkinen T, Järvinen A (2003) The common cold. Lancet 361: 51-59. [Crossref]

2. Hull D, Rennie P, Noronha A, Poore C, Harrington N, et al. (2007) Effects of creating a non-specific, virus-hostile environment in the nasopharynx on symptoms and duration of common cold. Acta Otorhinolaryngol Ital 27: 73-77. [Crossref]
3. Harris JM, Gwaltney JM Jr (1996) Incubation periods of experimental rhinovirus infection and illness. Clin Infect Dis 23: 1287-1290. [Crossref]

4. Allan GM, Arroll B (2014) Prevention and treatment of the common cold: making sense of the evidence. CMAJ 186: 190-199. [Crossref]

5. Blaas D, Fuchs R (2016) Mechanism of human rhinovirus infections. Mol Cell Pediatr 3: 21. [Crossref]

6. Sanjuán R, Domingo-Calap P (2016) Mechanisms of viral mutation. Cell Mol Life Sci 73: 4433-4448. [Crossref]

7. Rousse M, Cucuat N, Janicot C, Shrivastava R (2014) Innovative Scientific Concept of Topical Virus Glycoprotein Inhibitors Incorporated in Hyperosmotic Glycerol Revolutionizes Future Prospects in the Treatment of Viral and Bacterial Throat Infections. International Journal of Pharmaceutical Sciences and Drug Research 6: $1-11$.

8. Clarsund M, Fornbacke M, Uller L, Johnston SL, Emanuelsson CA (2017) A Randomized, Double-Blind, Placebo-Controlled Pilot Clinical Study on ColdZyme ${ }^{\circledR}$ Mouth Spray against Rhinovirus-Induced Common Cold. Open Journal of Respiratory Diseases 7: 125-135.

9. Kärber G (1931) Beitrag zur kollektiven Behandlung pharmakologischer Reihenversuche. N-S Arch Pharmacol 162: 480-483.

10. Poisson distribution (1999) International Conference on Harmonization (ICH) Topic Q5A.

11. Stefansson B, Helgadottir L, Olafsdottir S, Gudmundsdottir A, Bjarnason JB (2010) Characterization of cold-adapted Atlantic cod (Gadus morhua) trypsin I--kinetic parameters, autolysis and thermal stability. Comp Biochem Phys B 155: 186-94.

12. Asgeirsson B, Fox JW, Bjarnason JB (1989) Purification and characterization of trypsin from the poikilotherm Gadus morhua. Eur J Biochem 180: 85-94. [Crossref]

13. Gudmundsdóttir A, Pálsdóttir HM (2005) Atlantic cod trypsins: from basic research to practical applications. Mar Biotechnol (NY) 7: 77-88. [Crossref]

14. Stefansson B, Sandholt GB, Gudmundsdottir Á (2017) Elucidation of different coldadapted Atlantic cod (Gadus morhua) trypsin X isoenzymes. Biochim Biophys Acta 1865: 11-19. [Crossref]

15. Gudmundsdóttir A, Hilmarsson H, Stefansson B (2013) Potential use of Atlantic cod trypsin in biomedicine. Biomed Res Int 2013: 749078. [Crossref]

16. Linden SK, Sutton P, Karlsson NG, Korolik V, McGuckin MA (2008) Mucins in the mucosal barrier to infection. Mucosal Immunol 1: 183-197. [Crossref]

17. Fritz H (1988) Human mucus proteinase inhibitor (human MPI). Human seminal inhibitor I (HUSI-I), antileukoprotease (ALP), secretory leukocyte protease inhibitor (SLPI). Biol Chem H-S 369 Suppl: 79-82.

18. Hochstrasser K (1976) Proteinase (elastase) inhibitors from the ciliated membranes of the human respiratory tract, in Part B: Proteolytic Enzymes, Method Enzymol. Academic Press pp. 869-874.

19. Bown DP, Gatehouse JA (2004) Characterization of a digestive carboxypeptidase from the insect pest corn earworm (Helicoverpa armigera) with novel specificity towards C-terminal glutamate residues. Eur J Biochem 271: 2000-2011. [Crossref]

Copyright: (C2017 Stefansson B. This is an open-access article distributed under the terms of the Creative Commons Attribution License, which permits unrestricted use, distribution, and reproduction in any medium, provided the original author and source are credited. 